\title{
REGULARITIES OF CHANGES IN KEARNS TEXTURE COEFFICIENT AT COLD ROLLING OF $\mathrm{Zr}-2.5 \% \mathrm{Nb}$ ALLOY
}

\author{
(D)Viktor Grytsyna, (D)Dmitry Malykhin*, (D)Tetiana Yurkova, (D) Kostiantyn Kovtun, \\ Tetiana Chernyayeva, DGennadiy Kovtun, Vira Kornyeyeva, Olena Slabospitskaya, \\ Irina Tantsura, Viktor Voyevodin \\ NSC "Kharkiv Institute of Physics and Technology" NASU \\ Kharkiv, 61108, st. Akamemicheskaya 1, Ukraine \\ *E-mail:dmitr.malykhin@gmail.com
}

Received April 15, 2019; revised May 13, 2019; accepted May 16, 2019

X-ray studies of the changes in characteristics of crystallographic texture with cold deformation of $\mathrm{Zr}-2.5 \% \mathrm{Nb}$ alloy plates by longitudinal and cross rolling up to $56 \%$ at the speed of $5 \ldots 10 \mathrm{sec}^{-1}$ were carried out. The original plates were made from longitudinal fragments and rings cut from $\varnothing 15.0 \times 1.5 \mathrm{~mm}^{2}$ tube, and were then annealed at $580{ }^{\circ} \mathrm{C}$. Texture of the plates was studied by the method of inverse pole figures with calculation of the Kearns texture coefficient along the normal to the plate plane. Dependences of the texture coefficient on degrees of deformation of the plates are built. A discrepancy was found between texture coefficient values measured on different sides of the plates, which is associated with the straightening of the original tube fragments and invariance of " $c$ "-axes distribution after subsequent annealing of the initial plates. By introducing corrections to the degree of deformation calculated from the parameters of the cross section of the original tube, such discrepancies were eliminated for the data on cross-rolling of the material. As a result, for both deformation schemes, two stages of changes in the texture coefficient with alloy deformation were revealed: the initial stage of its growth and the subsequent stage of minor changes. Both stages are mainly linear and have the boundary value of the texture coefficient equal to $0.65 \ldots 0.68$. To study the structural mechanisms of changes in the texture of the alloy, an original technique of comparative analysis of changes in the texture coefficient of the material and in the distribution of crystallographic orientations is applied. It is established that at the initial stage of changes in the texture coefficient with deformation in both schemes, the rotation of the crystallographic " $c$ " axes of the material occurs abruptly, and it does at angles of more than $60^{\circ}$. This confirms the essential role of twinning in the texture changes of the alloy. In particular, we have shown that the initial stage is significantly dominated by the $\{10 \overline{1} 2\}\langle\overline{1} 011\rangle$ system of tensile twins. Connection of twinning with differences in texture changes at the longitudinal and cross rolling of the alloy is discussed.

KEYWORDS: zirconium alloys, rolling, XRD, texture, twinning

Investigation of crystallographic texture of materials is one of the applied and fundamental problems of materials science. Based on the texture data, one can either calculate or predict a large number of tensor characteristics of products made of materials with low symmetry crystal lattices: coefficient of thermal expansion [1,2], precipitate orientations [3], mechanical characteristics [4], as well as coefficients of thermal or electrical conductivity, and other characteristics. Products designed for use in nuclear reactors and made from materials with crystallographic anisotropy have a radiation growth, the rate of which also depends on their texture coefficients. This phenomenon is one of the main problems of reactor materials science [5-8].

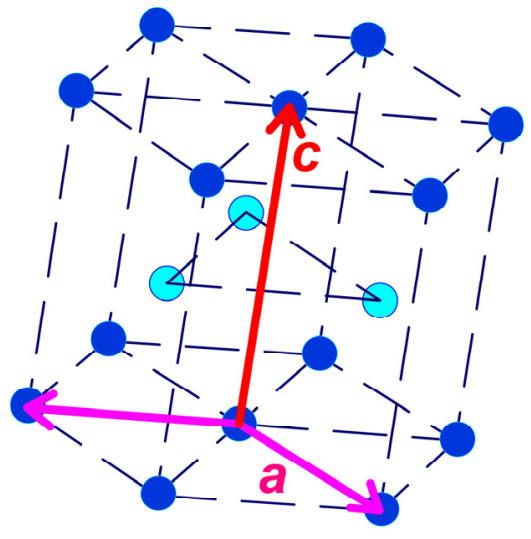

Fig. 1. Crystalline hep sell and its axes

In contrast to the method of direct pole figures widely used in recent times for texture studies, its prototype - the X-ray method of inverse pole figures (IPFs) [9-11] - has retained its principal advantages of simplicity and accuracy of defining the texture characteristics of materials that have biaxial crystallographic anisotropy and show quantitative relationship with the above characteristics of products. This applies to tubes made of zirconium alloys used in fuel assemblies of reactors on thermal neutrons.

The main characteristic for such analyses is the Kearns texture coefficient $(f)$, introduced for investigation of zirconium alloys [1]. This is a numerical characteristic of directionality of hep-lattice basal normals of grains in materials - their " $c$ " axes (Fig. 1) - along a given certain direction of the product: $f_{j}=\left\langle\cos ^{2} \alpha_{j i}\right\rangle$, where $\alpha_{j i}$ are the angles between the "c" axes (from the $i$-th orientations plurality) and this direction $(j)$. In cases of biaxial crystallographic anisotropy of the above characteristics, for example, for hcp metals, this can be expressed by the following formula [2]:

$$
q_{j}=\left(q_{c}-q_{a}\right) f_{j}+q_{a}
$$

where $q_{j}$ can be one of these characteristics with respect to the $j$-th direction, and could be represented by its basic values $\left(q_{a}, q_{c}\right)$. In particular, the radiation growth factor in a given direction of the product - the so-called texture coefficient of radiation growth - can be unambiguously determined by its texture coefficient: 


$$
G_{j}=1-3 f_{j} .
$$

This coefficient is an important characteristic, which is used to control and predict the radiation resistance of products made of nuclear materials with hcp lattice.

In this work, changes in the texture and texture coefficient of cold-rolled plates of $\mathrm{Zr}-2.5 \% \mathrm{Nb}$ alloy are studied. This material is used as a structural material of the central tubes of fuel assemblies and of the pressure tubes in the RBMK reactors. From a fundamental standpoint, the task is to study principles of texture changing of the material and the structural mechanisms accompanying it.

This study is associated with one of the elementary deformation schemes. It is expected that a set of such studies can help improve the texture prediction techniques, texture control criteria and related performance parameters, in particular, the radiation growth parameters of products made of hcp metals - zirconium alloy tubes used in nuclear reactor industry.

The task to precise the regularities obtained in [12], with especial experimental conditions of that, was also envisaged.

\section{EXPERIMENTAL}

\section{Preparation of samples}

For the research, the material of $\varnothing 15.0 \times 1.5 \mathrm{~mm}^{2}$ tube of $\mathrm{Zr}-2.5 \% \mathrm{Nb}$ alloy (finish annealing at $580{ }^{\circ} \mathrm{C}, 3 \mathrm{hrs}$.) was used. Table 1 shows the chemical composition of the material.

Table.

Chemical composition of the $\mathrm{Zr}-2.5 \% \mathrm{Nb}$ alloy

\begin{tabular}{|l|c|c|c|c|c|c|c|c|c|c|c|}
\hline Elements & $\mathrm{Zr}$ & $\mathrm{Nb}$ & $\mathrm{Fe}$ & $\mathrm{Hf}$ & $\mathrm{Cr}$ & $\mathrm{Sn}$ & $\mathrm{O}$ & $\mathrm{C}$ & $\mathrm{N}$ & $\mathrm{Si}$ & $\mathrm{H}$ \\
\hline wt. \% & 97.4 & 2.43 & 0.04 & 0.01 & 0.004 & - & 0.092 & 0.012 & 0.0036 & 0.0025 & 0.0017 \\
\hline
\end{tabular}

For investigations, longitudinal fragments, obtained by cutting the tube by its by-diameter plane, and rings of the tube were used after their straightening up to the plate shape and subsequent annealing in $1.5 \cdot 10^{-3} \mathrm{~Pa}$ vacuum at $580{ }^{\circ} \mathrm{C}$ for 24 hours.

The investigated surfaces of the samples were pretreated by chemical etching using a reagent with a volumetric combination of water, nitric acid, and hydrofluoric acid in ratio of 9: 5:1.5. The surfaces of the plates were etched up to $65 \mu \mathrm{m}$. This is the initial state of the plates. According to preliminary XRD measurements, it is this etching that eliminated the effects of near-surface non-uniformity of texture characteristics.

Further, the samples were deformed in a rolling mill DUO260 $\times 200$ at room temperature from 6 to $56 \%$ on the whole $\left(5 \ldots 7 \%\right.$ per pass) without intermediate annealing. The rate of deformation was $5 \ldots 10 \mathrm{~s}^{-1}$. Plates made of rings were rolled in the circumferential direction of the tube.

In view of the revealed differences between the texture coefficient values, texture measurements were carried out on both sides of the plates, and due to it, the corresponding designations of the sides were adopted: "outer" and "inner". For plates made of rings, changes in the texture coefficient were presented in the coordinates of the deformation of the pre-surface regions, taking into account the preliminary straightening of the tube fragments. The parameters of the tube section were used to calculate an additive correction to the degree of deformation of these areas, which in this case was added with the corresponding sign to the degree of deformation of the plate. This technique was considered permissible due to the identical geometry of the deformation of the pre-surface regions during both straightening and rolling. This guaranteed an absolute error of $0.5 \%$ for the aggregated deformation [12].

\section{On the IPFs method}

According to the principles of the texture method, the pole density $P_{j i}$ for each $i$ reflection is calculated from the set of integrated intensities $I_{j i}$ of X-ray reflections obtained by ordinary measurement in a given direction $(j)$ [11]:

$$
P_{j i}=\frac{1}{R_{j}} \frac{I_{j i}}{I_{0 i}} \quad\left(R_{j}=\sum_{i} A_{i} \frac{I_{j i}}{I_{0 i}}\right)
$$

where $I_{0 i}$ are the reflection intensities for the material in isotropic (non-textured) state; $A_{i}$ are the statistical weights of the $i$-th reflection [11] $\left(\Sigma A_{i}=\Sigma A_{i} P_{j i}=1\right)$.

To improve accuracy of the method, precise $A_{i}$ and $I_{0 i}$ values were determined. The $A_{i}$ values were mathematically calculated using the principle of construction of Wigner-Seitz cells [11] on the sphere of crystallographic orientations ( $h k i l)$ of crystal reflections. The set of $I_{0 i}$ values for a given alloy was obtained by synthesis of the calculated and experimental data. The latter were obtained on the basis of a series of studies on texture destruction of the given alloy by microwave heat treatment [13].

The set of $P_{j i}$ values obtained for the selected measurement directions was used to plot IPFs and to determine the texture coefficient for the selected measuring direction $(j)$, using the statistical summation technique [11]: 


$$
f_{j}=\left\langle\cos ^{2} \alpha_{i}\right\rangle_{j}=\sum_{i} A_{i} P_{j i} \cos ^{2} \alpha_{i}
$$

According to the results of testing of this method with the adjusted set of initial characteristics, the random error in determining the texture coefficients for the material is about \pm 0.003 .

We assume a possibility in principle to analyze the structural mechanisms leading to changes in the texture coefficient of the material and in " $c$ "-axes distributions.

Texture measurements were carried out on the DRON4-07 X-ray diffractometer using the radiation $\mathrm{CuK}_{\alpha}$. To reduce the vertical divergence of X-ray beam in this scheme, the pair of the Soller slits was used.

\section{RESULTS}

Figure 2 shows the IPFs plotted according to the results of texture measurements on the original $\mathrm{Zr}-2.5 \% \mathrm{Nb}$ tube along its radial, axial, and tangential directions. In the coordinates of longitudinal plate rolling, it corresponds to the normal direction (ND), the rolling direction (RD) and the transverse direction (TD), respectively. The density values of the basal (0002) and prismatic poles (hki0) are marked here and below, and a tone scale of $P_{j i}$ values is given.

As Figure 2 shows, the initial tube texture has a basic similarity with the ordinary texture of the plates after rolling in the same direction. We mean a fan-like distribution of the basal normals of the hcp lattice (the " $c$ " axes) in the crosssection plane. For the original sample, data of an X-ray scanning in the neighborhood of the ND have confirmed this, and have shown that, in the coordinates of axial section of the tube, the angular distribution of " $c$ " axes is localized within $\pm 25^{\circ}$ around ND. Thus, for plates made from longitudinal fragments of the tube and from its rings, the subsequent deformation can be defined, respectively, as longitudinal and transverse rolling.
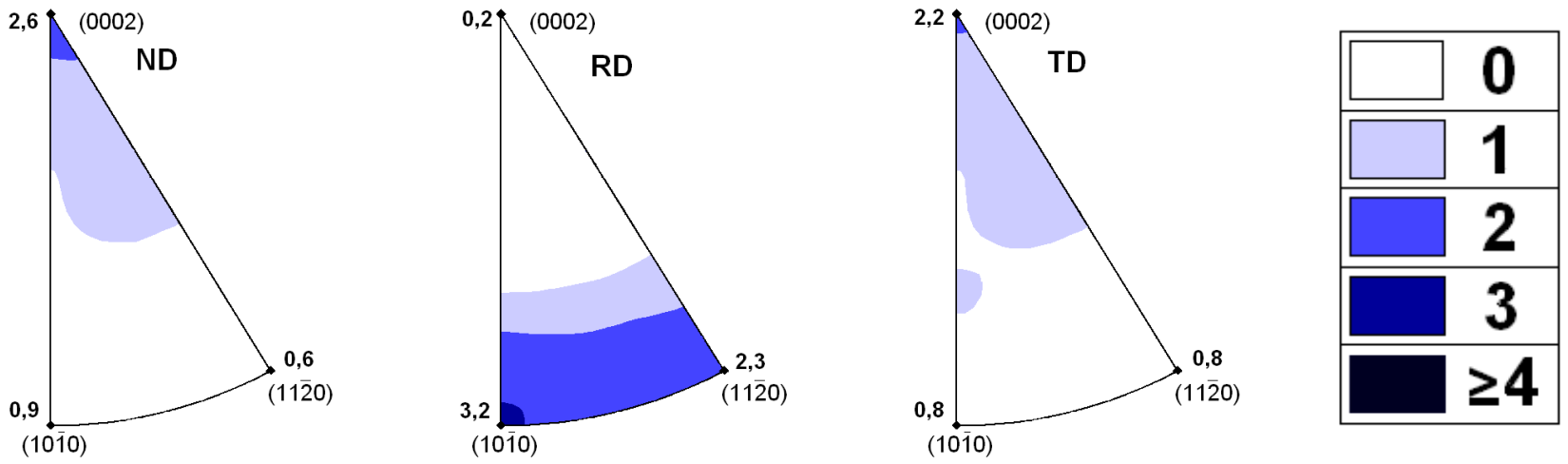

Fig. 2. IPFs of the tube in its three directions, given to the coordinates of longitudinal rolling plate [12]. The values of prismatic and basal pole densities are marked.
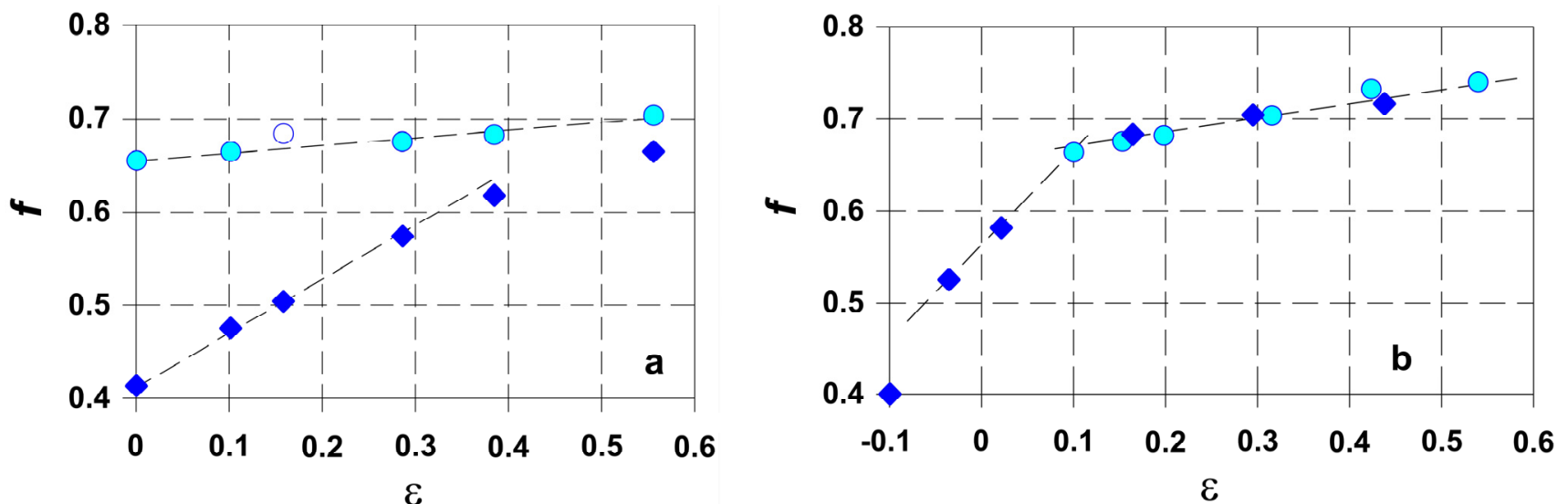

Fig. 3. Changes in the texture coefficient with the degree of plate deformation by longitudinal rolling (a) and of near-surface regions of the cross-rolled plates (b). Data from the plate sides which corresponding to the outer $(\bullet)$ and inner $(\circ)$ surface of the tube.

According to the metallographic examination, in the original samples (ann. $580^{\circ} \mathrm{C}, 24 \mathrm{hrs}$.), the $20 \mu \mathrm{m}$ grains were observed. Numerous $0.5 \mu \mathrm{m} \beta$ - $\mathrm{Nb}$ phase precipitates aligned along the rolling direction were also observed. According to the diffractometer data, the sizes of the mosaic blocks in the material are $150 \mathrm{~nm}$ and above, and the strains are $0.7 \cdot 10^{-3}$.

Figure 3a shows graphs of changes in the texture parameter on the "outer" and "inner" surfaces of the plates with the degree of deformation of the plates by longitudinal rolling. Figure $3 \mathrm{~b}$ presents similar data for the cross rolling of the plates, characterized in that the abscissa axis, according to the above, shows the actual degree of deformation of the 
near-surface regions of the plates associated with their preliminary straightening and obtained by addition the corrections to degree of deformation of plate.

\section{DISCUSSION}

Features of X-ray measurements of samples are associated with the thickness of the analyzed near-surface layer. For X-ray measurement of zirconium and its alloys in $\mathrm{CuK}_{\alpha}$ radiation, the thickness of such a layer is several microns. The effect of pre-straightening of the tube fragments, as it was meant, leads to differences in X-ray texture data on the different sides of the plates, due to their deformations of different signs. In this case, annealing of the alloy in the singlephase region (below $600^{\circ} \mathrm{C}$ ), as is known, does not change its texture in terms of "c"-axes distribution. Thus, in the prehistory of the samples, an effect of preliminary deformation of the surfaces remains, equivalent for the cross rolling of the plates in the tube coordinates.

In this regard, the main differences in the data on changes in the texture coefficient for the two differing deformation schemes is that the total effect of the deformation of the surface regions of different sides of the plates can be brought together only for cross rolling. This is shown in Figure $3 \mathrm{~b}$ and can be regarded as a result of the deformation of continuum of the material. For Figure 3a, data cannot be unambiguously merged, and each of its graphs should be considered separately.

Despite such difficulties, the material of tubes made from zirconium-niobium alloys remains an exceptional subject for textural studies, since it differs from plates, with their usual prehistory, by a more moderate initial texture, since, according to the analysis of subsequent data, under normal conditions for plate treatment, this alloy will lose the exceptionality after rolling by $60 \%$ or more.

\section{Graphical regularities}

Despite the above remarks, the moderate character of the initial texture on the "outer" sides of the plates leads to existence of the initial stage, which is characterized by significant changes in the texture coefficient with a degree of deformation (Fig. 3a,b). The texture coefficient is meant is calculated for the direction of the normal to the rolling plane. The subsequent (second) stages (round icons on the graphs) begin at $f \approx 0.65 \ldots 0.68$ and are characterized by small linear changes.

It should be noted that for cross rolling of the alloy plates, the boundaries between the stages in these studies (Fig. 3b) and in [12] coincide. At the same time, the second stage in this figure is lower than the previous results by about 0.07 . Some differences also occur at the initial stage. In general, such differences are associated with the specifics of the experimental conditions in previous work.

Taking into account the qualitative results of the work [12] and data from other preliminary studies gives grounds to assume that the initial stages of changes in the texture coefficient with the deformation of the plates (Fig. 3) are also mostly linear. Such signs are also shown by the initial stage in Figure 3b. However, with the first acts of deformation $(<5 \ldots 10 \%)$ deviations from linearity may exist. For example, the data of similar studies on hafnium can be regarded in such aspect (deformation up to 5\%; [14]). Such deviation was also noticed by us on this alloy after SHF (microwave) quenching and the subsequent initial rolling act by $7 \%$. We associate this effect with the details of the prehistory of the samples. In particular, the last example could be reasonably interpreted as a manifestation of the effect of stress relaxation [12]. Such examples are probably in Figure 3b.

If so, then the rate of change of the texture coefficient with the degree of cross rolling of the plates on the initial stage (Fig. 3b) is significantly lower than in the previous results. In this case, according to the analysis of the results (Fig. 3a,b), the rates of all changes at cross rolling should be about two times higher than at longitudinal rolling.

\section{On mechanisms of texture changes}

To study the mechanisms of texture changes, an original technique was used to analyze the character of the correlation of the texture coefficient with the volume fraction of grains, whose " $c$ " axes are oriented within $0 \ldots 30^{\circ}$ with the rolling plane. This fraction of grains gives "prismatic" reflections $(10 \overline{1} 0),(11 \overline{2} 0),(21 \overline{3} 0)$, and other ones, which close to them by crystallographic orientation. On the basis of the obtained data, we determined their portion in the samples $\left(c_{p}\right)$ using the following formula:

$$
c_{p}=\sum_{i} A_{i}^{\prime} P_{i} .
$$

The values of $A_{i}^{\prime}(5)$ represent the portions of the space of reflecting orientations that completely or partially falls within the assigned angular limits: $0 \leq A_{I}^{\prime} \leq A_{i}$. Figure 4 presents graphical comparing of the $f$ and $c_{p}$ values in the near-surface regions of the "outer" and "inner" sides of the plates for the longitudinal and cross rolling.

Despite the fact that the graphs in Figures $3 \mathrm{a}$ and $3 \mathrm{~b}$ have qualitative and quantitative differences, the graphs of the comparison of the data in Figures $4 a, b$ demonstrate a similarity. The figures show that at the initial stage of changes in the texture coefficient, its linear correlation is observed with the fraction of grains, whose " $c$ " axes are deflected more 
than $60^{\circ}$ from the normal direction of the plates. At that, in the process of deformation, the texture of the plates is formed by orienting the axes along the normal direction, and this is done at angles of $60 \ldots 90^{\circ}$. In this case, in view of the strong correlation, such acts occur abruptly, without intermediate positions.

It should be noted that the value of the derivative in the correlation graphs is approximately minus one. This fits into a simplified scheme of " $c$ "-axes directing. According to this scheme, with the rotation of the axes from the rolling plane into the normal direction, the texture coefficient of the reoriented grain fraction varies from zero to one. Totally for the plate, it does by the numerical portion value of these grains. This is possible due to the exclusive activity of twinning with rotations through an angle of $\approx 90^{\circ}$.

In this regard, it is known that in hop metals there are systems of compression and tensile twins $[15,16]$. Among the last ones, the twins of the system $\{10 \overline{1} 2\}\langle\overline{1} 011\rangle$, turning the " $c$ " axes of grains by $85^{\circ}$, are considered as the most active mechanism of texture formation at deformation. It is also considered that these twins, as well as other twinning systems, play an essential role in deformation texture of zirconium and its alloys [16, 17].
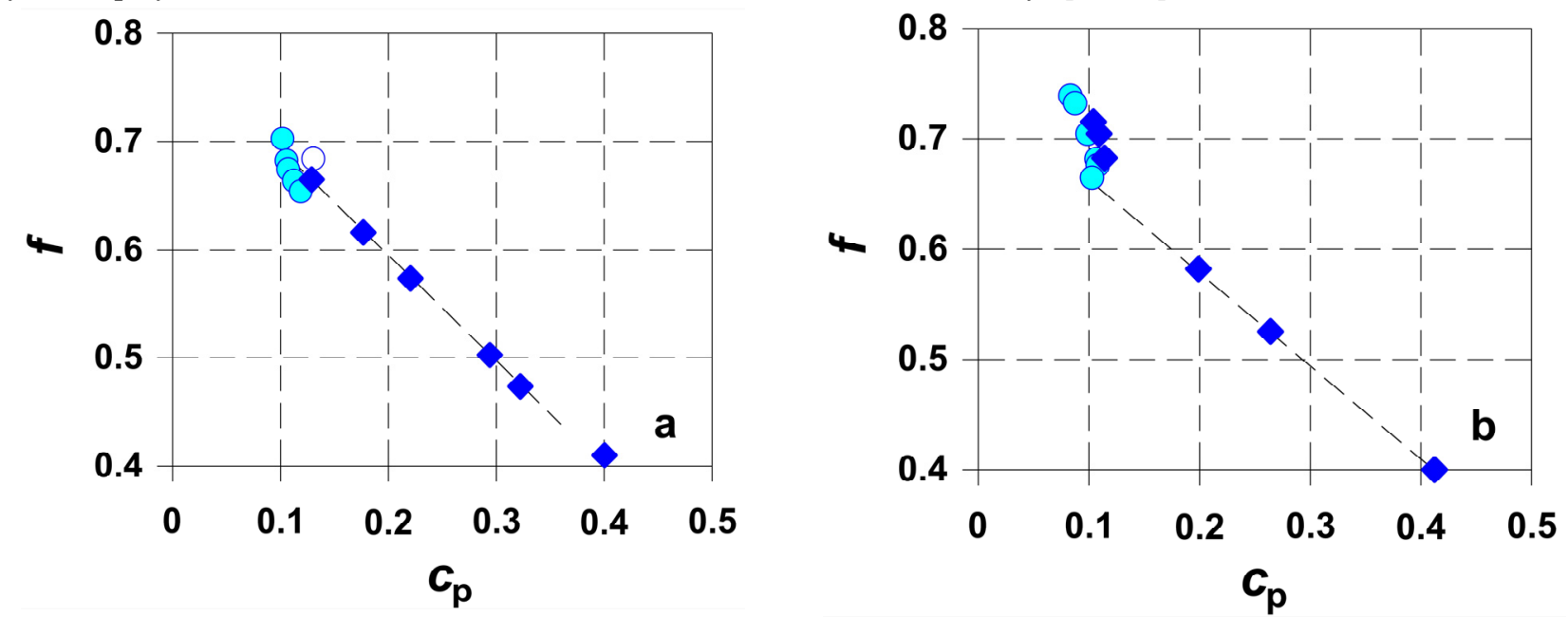

Fig. 4. Matching of the texture coefficient values (Fig. 3) with the numerical part of " $c$ " axes orientations within $0 \ldots 30^{\circ}$ from the rolling plane for longitudinal (a) and cross (b) rolling of the plates. Marking of points is the same.

The obtained results confirm this conclusion regarding metals of the titanium subgroup, including zirconium and its alloys. According to our results, the system $\{10 \overline{1} 2\}\langle\overline{1} 011\rangle$ of tensile twins is the main factor for changes in the texture coefficient at the initial stage of deformation.

As noted, such an initial stage exists when the initial values of the texture coefficient (measured in ND) are below 0.65 , especially if there is a fraction of orientations of the " $c$ " axes in the neighborhood of directions lying in the rolling plane. The dominant activity of such a system was identified, in particular, in zirconium plates, however, under special conditions of deformation [18]. In the studies of this kind, should such initial stage be practically absent, a conclusion might differ [19].

According to preliminary estimates, the results obtained fit into simple geometric schemes of texture coefficient changes at the initial stage of longitudinal and cross rolling of this alloy. This aspect is discussed.

Effect of non-uniformity of deformation of the plates, what could arise along their thickness at rolling process, on their texture will also studied further.

\section{CONCLUSIONS}

Using the method of inverse pole figures (IPFs) with X-ray measurements as the basis, we have investigated the crystallographic texture of the $\mathrm{Zr}-2.5 \% \mathrm{Nb}$ plates, which were made of straightened segments of the $\varnothing 15.0 \times 1.5 \mathrm{~mm}^{2}$ tube, annealed for 24 hours at $580{ }^{\circ} \mathrm{C}$ and were cold-worked from 6 to $56 \%$ by longitudinal and cross rolling. Calculations of the Kearns texture coefficients for the direction perpendicular to the rolling plane of samples have been carried out. Effects of both near-surface and bulk non-uniformities were taken into account at preparation of the samples and at processing of the results.

The principal character of texture coefficient changes of the material with deformation in both schemes of rolling has been established. In both cases, this involves the existence of an initial stage of significant increase of texture coefficient up to $\sim 0.7$, and the subsequent stage of minor changes. It is noted that changes in the texture coefficient at each stage are mainly linear. Rates of the changes have been estimated. Existence conditions for the initial stages are clarified.

The original method of studying the mechanisms of deformation of the alloy in a comparative analysis of changes in the texture coefficient of the material and in its distribution of crystallographic orientations was used. Correlations of the characteristics of the initial stage with the features of the distributions of the " $c$ " axes of the hcp lattice in the alloy are established. 
It is noted that more than $90 \%$ of quantitative changes of the texture coefficient in the initial stage of plate deformation is related to abrupt turns of crystalline fragments through wide angles to the normal direction involved with rolling. This confirms the fact that the texture formation by rolling of $\mathrm{Zr}-2.5 \% \mathrm{Nb}$ plates is caused by a dominant role of twinning, especially, at the initial stage. An exclusive activity of the $\{10 \overline{1} 2\}\langle 1011\rangle$ system of tensile twins at the initial stage of growth of the texture coefficient has been revealed.

\section{ACKNOWLEDGEMENTS}

The authors are grateful to Dr. V.S. Krasnorutsky for promotion of the direction of the researches.

\section{ORCID IDs}

Viktor Grytsyna @https://orcid.org/0000-0003-4341-007X, Dmitry Malykhin @https://orcid.org/0000-0003-0259-0211, Tetiana Yurkova $@$ https://orcid.org/0000-0003-1264-640X, Kostiantyn Kovtun@https://orcid.org/0000-0002-0524-5053, Gennadiy Kovtun 1 https://orcid.org/0000-0003-4242-7697.

\section{REFERENCES}

[1]. Kearns, WAPD-TM-472, Westinghouse Electric Corporation, Pittsburg, Pa. USA (1965).

[2]. P.A. Tempest, J. Nucl. Mater. 92(2-3), 191-200 (1980), doi: 10.1016/0022-3115(80)90102-6.

[3]. J.J. Kearns and C.R. Woods, J. Nucl. Mater. 20(3), 241-261 (1966), doi: 10.1016/0022-3115(66)90036-5.

[4]. V.M. Allen, M. Preuss, J.D. Robson and R.J. Comstock, Mater. Sci. Forum 495-497, 675-80 (2005), doi : 10.4028/www.scientific.net/MSF.495-497.675.

[5]. J.J Stobo and B. Pawelski, J. Nucl. Mater. 4(1), 109 (1961), doi: 10.1016/0022-3115(61)90155-6.

[6]. E.F. Sturcken and W.R. McDonell, J. Nucl. Mater. 7(1), 85-91 (1962), doi: 10.1016/0022-3115(62)90196-4.

[7]. R.A. Murgatroyd and A. Rogerson, J. Nucl. Mater. 79(2), 302-311 (1979), doi: 10.1016/0022-3115(79)90095-3.

[8]. A. Rogerson and R.A. Murgatroyd, J. Nucl. Mater. 80(2), 253-259 (1979), doi: 10.1016/0022-3115(79)90188-0.

[9]. G.B. Harris, Phil. Mag. 43(336), 113-123 (1952), doi: 10.1080/14786440108520972.

[10]. A. Guinier, Théorie et Technique de la Radiocristallographie, 2nd ed. (Paris, 1956) 736 p. (in French)

[11]. P.R. Morris, J. Appl. Phys. 30(4), 595-596 (1959), doi: 10.1063/1.1702413.

[12]. V.M. Grytsyna, D.G. Malykhin, T.S. Yurkova, K.V. Kovtun, T.P. Chernyayeva, G.P. Kovtun and V.N. Voyevodin, Physics of Radiation Effect and Radiation Materials Science, 5(117), 69-74 (2018).

[13]. V.M. Grytsyna, A. Stukalov, T. Chernyayeva, V. Krasnorutskyy, D. Malykhin, V. Voyevodin, and V. Bryk, J. ASTM International, 2(8), 1-22 (2005), doi: 10.1520/JAI12339.

[14]. D. Malykhin, G.P. Kovtun and T.S. Potina, Problems of Atomic Science and Technology 1, 35-40 (2016).

[15]. E.A. Calnan and C.J.B. Clews, Phil. Mag. 42(331), 919-931 (1951), doi: 10.1080/14786445108561320.

[16]. E. Tenckhoff, J. ASTM International 2(4), 1-26 (2005), doi: 10.1520/JAI12945.

[17]. C.N. Tome', R.A. Lebensohn and U.F. Kocks, Acta Metall. Mater. 39(11), 2667-2680 (1991), doi: 10.1016/09567151(91)90083-D.

[18]. R.J. McCabe, G. Proust, E.K. Cerreta and A. Misra, International Journal of Plasticity, 25(3), 454-472 (2009), doi: 10.1016/j.ijplas.2008.03.010.

[19]. Bai-feng Luan, Qing Ye, Jian-wei Chen, Hong-bing Yu, Dong-li Zhou and Yun-chang Xin, Trans. Nonferr. Met. Soc. China 23(10), 2890-2895 (2013), doi: 10.1016/S1003-6326(13)62811-3.

\section{ЗАКОНОМІРНОСТІ ЗМІН ТЕКСТУРНОГО ПАРАМЕТРА КЕРНСА ПРИ ХОЛОДНІЙ ПРОКАТЦІ СПЛАВУ $\mathrm{Zr}-2.5 \% \mathrm{Nb}$}

Грицина В.М., Малихін Д.Г., Юркова Т.С., Ковтун Г.П., Ковтун К.В., Корнсєва В.В., Слабоспицька О.А., Танцюра І.Г., Чернясва Т.П., Восводін В.М.

Національний Науковий Центр «Харківський фізико-технічний інститут» 61108, Харків, вул. Академічна, 1

Проведено рентгенівські дослідження закономірностей змін характеристик кристалографічної текстури при холодній деформації пластин зі сплаву $\mathrm{Zr}-2,5 \% \mathrm{Nb}$ шляхом поздовжньої і поперечної прокатки до 56\% зі швидкістю приблизно $5 \ldots 10$ сек $^{-1}$. Вихідні пластини було виготовлено з поздовжніх фрагментів і кілець, вирізаних з труби $\varnothing 15,0 \times 1,5$ мм², і потім відпалено при $580^{\circ} \mathrm{C}$. Текстуру пластин досліджено за методом зворотних полюсних фігур з розрахунком текстурного параметра Кернса уздовж нормалі до площини пластин. Побудовано залежності текстурного параметру від ступеня деформації пластин. Виявлено розбіжність значень текстурного параметру, виміряного на різних сторонах пластин, що зв'язується з випрямленням вихідних заготівок труби і незмінністю розподілу кристалографічних осей «с» після наступного відпалу вихідних пластин. Шляхом введення поправок до ступенів деформації, розрахованих за параметрами перетину вихідної труби, такі розбіжності було усунуто для даних з поперечної прокатки матеріалу. В результаті для обох схем деформації виявлено дві стадії змін текстурного параметра з деформацією сплаву: початкову стадію зростання і подальшу стадію незначних змін. Обидві стадії мають, в основному, лінійний характер з граничним значенням текстурного параметра 0,65 ... 0,68. Для дослідження структурних механізмів змін текстури сплаву застосовано оригінальний прийом порівняльного аналізу змін текстурного параметра матеріалу та розподілу кристалографічних орієнтацій. Встановлено, що на початковій стадії змін текстурного параметру з деформацією за обома схемами повороти кристалографічних осей «с» матеріалу відбуваються стрибкоподібно на кути більш за $60^{\circ}$. Це підтверджує суттєву роль двійникування у текстурних змінах сплаву. Зокрема, нами показано, що на початковій стадії значно домінує система $\{10 \overline{1} 2\}\langle\overline{1} 011\rangle$ двійників розтягування. Обговорюється зв'язок двійникування з особливостями текстурних змін при поздовжній і поперечній прокатці сплаву.

КЛЮЧОВІ СЛОВА: сплави цирконію, прокатка, рентгенографія, текстура, двійникування 


\section{ЗАКОНОМЕРНОСТИ ИЗМЕНЕНИЙ ТЕКСТУРНОГО ПАРАМЕТРА КЕРНСА \\ ПРИ ХОЛОДНОЙ ПРОКАТКЕ СПЛАВА $\mathrm{Zr}-2.5 \% \mathrm{Nb}$ \\ Грицина В.М., Малыхин Д.Г., Юркова Т.С., Ковтун Г.П., Ковтун К.В., Корнеева В.В., Слабоспицкая Е.А., Танцюра И.Г., Черняева Т.П., Воеводин В.Н. \\ Начиональный Научный Центр «Харьковский физико-технический институт» \\ 61108, Харьков, ул. Академическая, 1}

Проведены рентгеновские исследования закономерностей изменений характеристик кристаллографической текстуры при холодной деформации пластин из сплава $\mathrm{Zr}-2,5 \% \mathrm{Nb}$ путём продольной и поперечной прокатки до $56 \%$ со скоростью примерно $5 \ldots 10$ сек $^{-1}$. Исходные пластины были изготовлены из продольных фрагментов и колец, вырезанных из трубы $\varnothing 15,0 \times 1,5$ мм $^{2}$, и затем отожжены при $580^{\circ} \mathrm{C}$. Текстура пластин исследована методом обратных полюсных фигур с расчётом текстурного параметра Кернса вдоль нормали к плоскости пластин. Построены зависимости текстурного параметра от степени деформации пластин. Выявлено расхождение значений текстурного параметра, измеренного на разных сторонах пластин, что связывается с выпрямлением исходных заготовок трубы и неизменностью распределения кристаллографических осей «с» после последующего отжига исходных пластин. Путём введения поправок к степени деформации, рассчитанных по параметрам сечения исходной трубы, такие расхождения были устранены для данных по поперечной прокатке материала. В результате для обеих схем деформации выявлено две стадии изменений текстурного параметра с деформацией сплава: начальную стадию роста и последующую стадию незначительных изменений. Обе стадии имеют, в основном, линейный характер с граничным значением текстурного параметра 0,65...0,68. Для исследования структурных механизмов изменений текстуры сплава применён оригинальный приём сравнительного анализа изменений текстурного параметра материала и распределения кристаллографических ориентаций. Установлено, что на начальной стадии изменений текстурного параметра с деформацией по обеим схемам повороты кристаллографических осей «с» материала происходят скачкообразно на углы более $60^{\circ}$. Это подтверждает существенную роль двойникования в текстурных изменениях сплава. В частности, нами показано, что на начальной стадии значительно доминирует система $\{10 \overline{1} 2\}\langle\overline{1} 011\rangle$ двойников растяжения. Обсуждается связь двойникования с различиями текстурных изменений при продольной и поперечной прокатке сплава.

КЛЮЧЕВЫЕ СЛОВА: сплавы циркония, прокатка, рентгенография, текстура, двойникование 